\title{
Nasal tip schwannoma mimicking rhinophyma
}

\author{
Thomas Geyton, Arthur Harry Henderson, James Morris, Steve McDonald
}

Department of ENT Surgery, Royal United Hospitals NHS Trust, Bath

\section{Correspondence to}

Dr Thomas Geyton,

Geyton@gmail.com

Accepted 2 December 2017

\section{DESCRIPTION}

Rhinophyma meaning 'nose growth' in Greek is a relatively common condition that describes

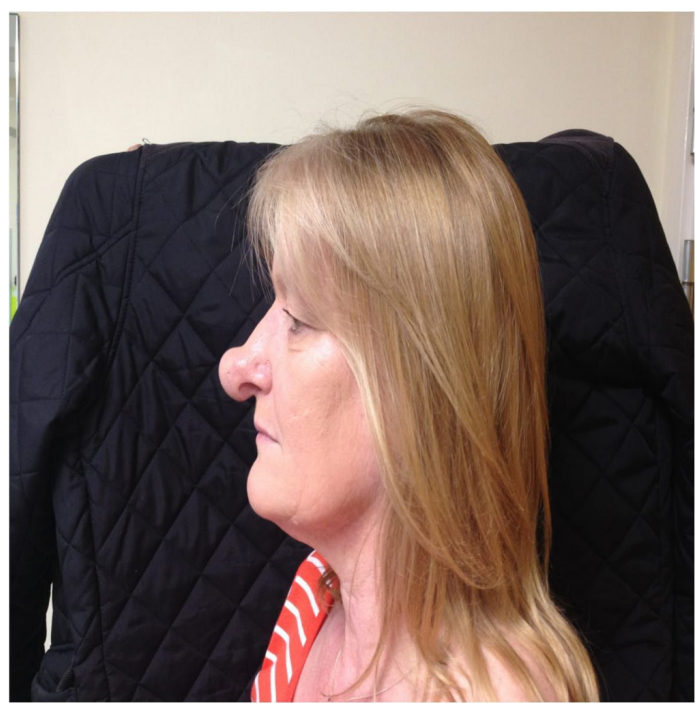

Figure 1 Clinical features consistent with rhinophyma centred on the tip of the nose, giving a markedly distorted appearance to the nasal tip.

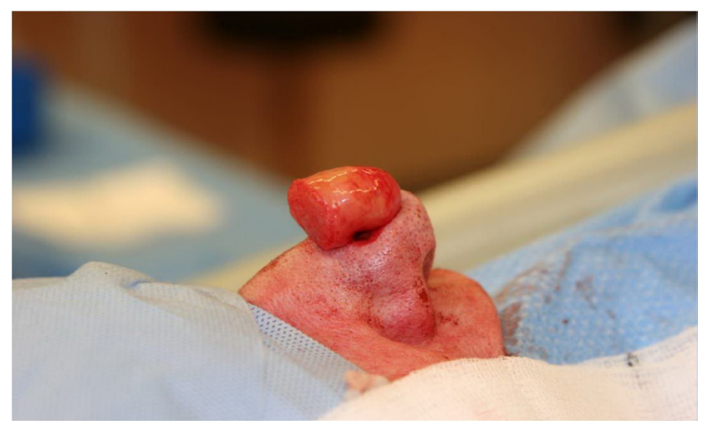

Figure 2 Intraoperative image displaying rubbery soft tissue mass delivered through initial incision.

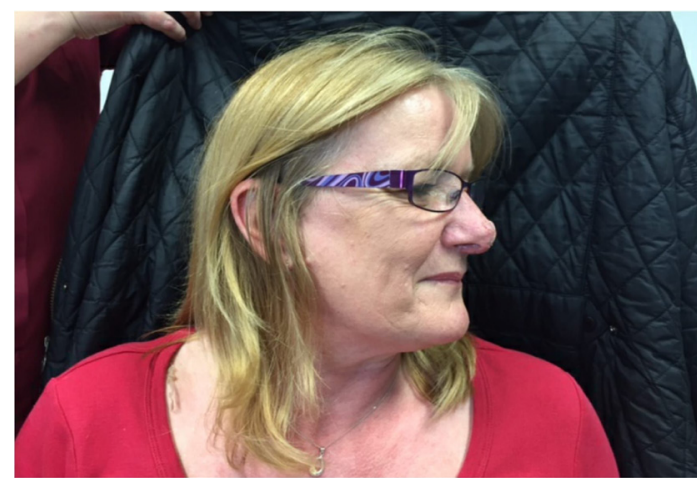

Figure 3 Appearance at 3 months following surgery. thickening of the nasal skin with enlargement of the sebaceous glands. While not fully understood, it is believed to be a result of vascular instability causing leakage of fluid into the tissues. This subsequently triggers inflammation and scarring. ${ }^{1}$ Treatment is initially medical; systemic isotretinoin has been shown to reduce the bulk of rhinophyma. Many surgical techniques have also been described, all of which involve tissue removal. Previous literature has demonstrated other skin conditions mimicking this diagnosis including angiosarcoma, squamous cell carcinoma and sarcoidosis. ${ }^{2}$

A 52-year-old woman was referred to ear, nose and throat (ENT) from dermatology for surgical management of rhinophyma. She described a 3-year history of an increasing swelling on the tip of her nose (figure 1). During this time, she underwent extensive conservative treatment with dermatology including a course of isotretinoin to little effect. The appearance of her nose had been causing a significant influence on her mental health and social well-being. She had been prescribed antidepressants by her general practitioner and was reluctant to progress in her career, as this would include more contact with the general public.

At first skin incision with a scalpel, instead of the anticipated rhinophyma, a large subdermal mass was unexpectedly encountered (figure 2). This was removed without difficulty, and a good cosmetic result was achieved by reshaping/regrafting the removed skin flap. The mass was sent for histology which surprisingly identified it as a schwannoma. Follow-up at 2 weeks and 3 months confirmed a good cosmetic outcome and patient satisfaction (figure 3). No further management was required.

Schwannomas are benign tumours of the nerve sheath that are composed of Schwann cells. They account for between $25 \%$ and $45 \%$ of head and neck tumours of which $4 \%$ are found in the nasal cavity. Schwannomas of the nasal tip are rare with only a handful of cases previously being reported. ${ }^{3}$ Preoperative diagnosis can be made based on biopsy or imaging studies where there

\section{Learning points}

- Nasal tip schwannoma is a rare differential diagnosis when considering rhinophyma.

- Biopsy and imaging prior to surgery may help where there is diagnostic uncertainty, therefore allowing better surgical planning.

- If this patient had undergone treatment by microdebridement, a rapid and good cosmetic outcome may have been more difficult to achieve. 
is clinical suspicion. This was not undertaken in this case as both ENT and dermatology agreed on the clinical diagnosis of rhinophyma.

Preoperative MRI may have helped identify the schwannoma given the tumour's predictable signal characteristics. A number of signs on MRI have been described including the split-fat sign, target sign and fascicular sign. ${ }^{4}$ Histology typically shows an encapsulated well-circumscribed lesion beneath the uninterrupted epidermis. The tumour is composed of areas that are composed of different cellular densities.

Contributors TG wrote the manuscript. AHH, JM and SM were involved in clinical care and revision of manuscript.

Competing interests None declared.
Patient consent Obtained.

Provenance and peer review Not commissioned; externally peer reviewed.

(C) BMJ Publishing Group Ltd (unless otherwise stated in the text of the article) 2017. All rights reserved. No commercial use is permitted unless otherwise expressly granted.

\section{REFERENCES}

1 Rohrich RJ, Griffin JR, Adams WP. Rhinophyma: review and update. Plast Reconstr Surg 2002;110:860-70

2 Sand M, Sand D, Thrandorf C, et al. Cutaneous lesions of the nose. Head Face Med 2010;6:7.

3 Skouras A, Skouras G, Diab A, et al. Schwannoma of the nasal tip: diagnosis and treatment. Aesthetic Plast Surg 2011;35:657-61.

4 Lemmerling M, Moerman M, Govaere F, et al. Schwannoma of the tip of the nose: MRI. Neuroradiology 1998;40:264-6.

Copyright 2017 BMJ Publishing Group. All rights reserved. For permission to reuse any of this content visit http://group.bmj.com/group/rights-licensing/permissions.

BMJ Case Report Fellows may re-use this article for personal use and teaching without any further permission.

Become a Fellow of BMJ Case Reports today and you can:

- Submit as many cases as you like

- Enjoy fast sympathetic peer review and rapid publication of accepted articles

- Access all the published articles

Re-use any of the published material for personal use and teaching without further permission

For information on Institutional Fellowships contact consortiasales@bmjgroup.com

Visit casereports.bmj.com for more articles like this and to become a Fellow 